\title{
TOWARDS A PROTOTYPICAL CATEGORIZATION OF DISTANCE EDUCATION IN TEACHER EDUCATION
}

\author{
Andy Thys, Luc Vandeput, Jan Elen, University of Leuven, Belgium
}

\section{Abstract}

Higher Education is in constant transition. In the Flemish context this is illustrated by a gigantic transformation in teacher education (TE). In the context of this transformation Educational master-level programs (EQF 7 - VKS 7) are designed and will be implemented in 2019-2020. The main factor that has to be taken into account is the a priori choice to offer the master programs at different locations throughout the Flemish region. This demands from the new educational masters in TE a radical focus on multi-campus education. This article stresses the need to establish a strong vision on distance education (DE) in TE. To do so a typology of distance education in teacher education is developed. Elen et al. (2014) can be seen as a prime inspiration for the different approaches (of distance education in teacher education).

At the core of this article are the three outlined approaches as a basis for discussion. A methodology is presented to systematically sketch this process and its future aspirations. It has to be noted that this search for prototypes can never be seen as a fixed description but as a constant search and debate.

\section{Context}

At the core of this contribution are the descriptions of three prototypes of distance education (in teacher education). As an introduction, we first outline the background of this proposal by pointing at elements on three different levels.

\section{Macro-level}

At a Macro-level diverse challenges are arousing in the field of teacher education. Without being exhaustive four interrelated factors can be laid out. These are globalization and its impact on (higher) education, the rise of MOOCs (in higher education), the regional/national (and global) teacher shortage and probably the most pertinent, the decision of the Flemish government to launch educational masters at universities.

\section{Meso-level}

At the meso-level or program level there is a clear need to make well-informed choices regarding educational practices and, more specifically, about the use of distance education. Designing new courses within the new educational master programs (but also educational 
bachelors and graduates) can benefit from a typology of distance education in TE. Regarding the quality of DE, Wheeler (2012; p.1019) states that "distance education, when managed effectively, can provide remote learners with an equivalent quality of experience to leaners studying in more traditional setting". This statement clearly shows the possibility of distance education to provide quality education. The prototypes may help institutions in making adequate decisions with respect to distance education and to provide quality in distance education.

\section{Micor-level}

The micro-level covers the interactions between the student and different aspects of the learning environment (e.g. interaction within a digital learning environment between teacher and student). The assumption is made that a typology can guide teacher educators and designers in making informed choices about the learning environment. Future research can show to what extent the presented typology is experienced as a scaffold for teacher educators in their day-to-day job.

Nonetheless, the key point is to stimulate TE programs to position themselves in one of the approaches, so they can think differently about teacher education at remote locations, university colleges and universities. As a spill-over this article can support the establishment of a research agenda towards distance education in teacher education.

\section{Method}

Three consecutive steps can be distinguished in this paper: First the construction of the prototypes was strongly inspired by Elen et al. (2014). This conceptual article shows the necessity to think about different approaches to ICT-integration in Flemish education based on large scale surveys (see MICTIVO). The idea of working with prototypes to increase the quality in programs was adopted. Second the use of roundtable discussions is described. Third and last the proposed activity at EDEN 2019 is expressed. These steps are an attempt to validate the prototypes and dimensions through an iterative process with an extensive group of (educational) stakeholders.

\section{Constructing the prototypes}

To make a connection between the two central concepts in this contribution (DE and TE), the authors present three prototypes/approaches. The approaches are constructed as a basis for debate and discussion with other teacher education institutions. This is represented in the method used. To distinguish these types of approaches different source materials were used. After selection based on an exploratory literature study (see e.g. Ossiannilsson \& Landgren, 2012; Ehlers, 2006) five dimensions were distracted on which the prototypes might differ. These are: (a) integration of research and practice, (b) possibilities towards innovation, (c) designing of learning environments, (d) policy and support and (e) the role of the teacher trainer. Each of these five dimension will be discussed in the presentation of the three approaches. 


\section{Roundtable}

Once the prototypes have a stable (qualitative) description roundtable discussions with different stakeholders will be organized (the roundtables are still on-going). During these roundtable discussions two central questions are put forward: Can these prototypes be a first step towards a vision on DE in TE? Second, can these prototypes act as scaffolds for designing and implementing distance education in teacher education? Answers to these questions are rather complex and can't be given in one session. In order to get in-depth discussions different rounds of roundtables are organized with a semi-structured set of questions. The five previously mentioned dimensions will be used to structure the discussion. Input from different roundtables will be summarized in a plenary session, in order to get a full and comprehensive view on the above-mentioned questions.

\section{EDEN 2019}

Prototypes (as they stand) will be presented during the EDEN 2019 session. Second the participants will be integrated in the methodology by participating in a concluding roundtable. This will result in a final version of the prototypes.

\section{Participants}

A diversified group of participants will be invited to the roundtable discussions. Without being exhaustive these are: teacher educators, heads of programs, institutional experts of supportive services, researchers, learning path counsellors and students from universities and university colleges. These participants will be grouped in alternate sessions to get a diverse image of the presented issue.

\section{Three approaches towards distance education in teacher education: a first proposal}

The literature and a first analysis indicate that three prototypes can be identified based on the question on the central role of 'distance education': a leaner-centred approach, a modelling approach and a anticipating approach. The approaches also evoke speaking images about DE in TE, these will be added at the end of each approach.

\section{Approach 1: A learner-centred approach toward distance teacher education}

In this first approach, institutions for teacher education take a stance towards distance education that appeals to requests of the learner: more specifically, requests from students concerning for a teacher education program that is ubiquitous and hence, independent from time and place.

Research and follow-up aren't core values of the institution (and/or program) but can nonetheless be present mostly based on ad hoc initiatives.

Innovation is mainly directed at serving the student, making the TE program as flexible and ergonomic as possible. 
With respect to the learning environment mainly teachers and sometimes designers use an ad hoc approach. In most cases the learning environment is implemented by one person with maximal adoption towards learners' requests. In other words, this approach tends to focus on adaptive learning environments for the students. Technology in this first approach is more used to distribute teaching materials and to stimulate learning by means of one-way or twoway communication (Albright et al., 2009; p.37).

The policy is primarily related to "marketing" and so the student is regarded to be a consumer who needs to be pleased. This for example manifests itself in large scale (student-centred) satisfaction surveys.

In this first approach the role of the teacher trainer is limited to instructor and evaluator, thus an individual teacher educator is responsible for testing and supporting the learning goals. In some cases, he/she can also be described as an ad hoc designer of learning environments.

In a metaphor, this approach can be labelled as the servant or the waiter, always very keen on servicing his clients.

\section{Approach 2: A modelling approach toward distance teacher education}

The exemplary approach confronts future teachers with the possibilities (and limitations) of distance learning in practice. By doing this, students experience distance education in an exemplary manner. This approach models so called good practices of distance education in preparation of future teachers.

Research and projects aim at optimizing the support of learning processes through the use of evidence-based teaching practices. The research and projects reflect the current understanding of distance education and are in line with on-going developments (e.g., how to organize co-teaching, how to use tablets in the classrooms).

Innovations in this approach tends to be focused on including more diverse student populations, becoming more elaborated for a broader range of learning goals and signal new developments in education.

In order to design learning environments that can be characterized as modelling, the design and implementation process are carried out by colleagues/teams using a systematic design and development.

To constantly be seen as a modelling teacher education program oriented towards offering high quality distance education, resources are made available to support the development of high-quality learning environments. Consequently, the teacher program can be seen as an 'example' of good practices and so this implies study visits and training from other teacher training institutions.

In this second approach the teacher educator aims to be an example and thus is a mentor, a coach and a designer in distance education (also see "guide on the side teacher"). 
For this second approach the image of the "proud sport champion" comes to mind. A person who, through many effort, creates a buzz around him and his sport and by doing so attracts others.

\section{Approach 3: An anticipating approach towards distance teacher education}

Distance education is not a means for an end but the starting point for designing and developing TE. By taking distance education as a constituent, the approach questions leading practices. Or in other words, this approach shows a vision on distance education that is a catalyst to seriously question existing teaching practices (e.g. Why use fixed class groups? What's the role of physical presence in TE? What's the place of ad hoc constructed learning materials? etc.). This approach also includes diverse approaches to Blended Learning. Therefore, alignment throughout different dimensions of the program is a necessity in this anticipating approach (Biggs, 2003).

Research in this approach dares to question leading practices and generally assumed activities with emphasis on learning, teaching, teacher training and the societal role of education. As a logical consequence innovation in different educational settings is always at the forefront of research. In this dimension the 'pro-active' aspect is prominent on the agenda.

The innovations are closely linked with the research being done. Innovations start from the question on how regular problems can be solved by assuming that distant education is at the core, in other words that teachers' presence is only essential in very specific circumstances. From that radical starting point it is wondered how teacher education can be effective (resulting in excellent student learning outcomes) and sustainable. Examples can be seen in the use, make and share of Open Educational Resources (OER), the attention towards developing a disposition towards critical thinking stimulation, close relationships with partner(schools) in order to test and research educational innovations.

The dimension "designing of learning environments" can be characterized in this approach by four notions. First the design is always planned, thus never a so-called ad hoc design. This is particularly seen in the timing of the design process. The design is made long in advance to make sure there is the ability to get feedback from different stakeholders on the design. Linked with this, second, the designing of learning environments is always a team endeavour. Or in other words, it's well recognized that achieving high-quality materials and experiences and more satisfactory teaching and learning experiences, requires (or it's at least desirable to apply) a team-based approach (see e.g. Hirumi, 2002). Third, in order to get a qualitative and well-balanced learning environment the team responsible for the course maximizes the use of the present support (local, regional, national and international) at hand. A forth characteristic that is at stake here is what Hannafin et al. (1997) define as grounded design: "the systematic implementation of processes and procedures that are rooted in established theory and research in human learning" (p.102). This can be seen in the design that is neither teachercentred or student-centred, but always learning-centred with an emphasis on technology integration. 
As to policy and support, this third (challenging) approach represents a policy that takes distance education as self-evident, is integrated and widespread in order to establish these challenging practices. This can be seen in policies and practices towards special needs education (e.g. UDL), assessment policy that is aligned with policies on distance education, HR-policy, etc.

It's noteworthy to mention that the role of the teacher educator in this third approach is complex and multi-layered. Teacher educators are facilitators of learning, innovators in education; they are researchers, (co-)designers, and so on and in addition they are fundamental change agents that are oriented not only towards innovation but towards transformation.

In this third approach the question rises, who is the student? It is not so farfetched that the recruitment of students is no longer a regional aspect but has an international order of magnitude.

Institutions applying this approach try to anticipate to evolutions and societal challenges (e.g. teacher shortage, rise of educational technologies). In this sense these programs can't be seen as teacher training programs but are always teacher education (see e.g. Masschelein \& Simons 2012).

This last approach can be depicted as a surrealist painter. Surrealism is many times seen as a revolutionary movement, a questioning of existing practices and ideas, affecting various fields (visual arts, philosophy, politics, literature, etc.). About his painting “The Son of Man” René Magritte pointed out that: "Everything we see hides another thing. We always want to see what is hidden by what we see. There is an interest in that which is hidden and which the visible does not show us. This interest can take the form of a quite intense feeling, a sort of conflict, one might say, between the visible that is hidden and the visible that is present.".

\section{Discussion}

This proposal attempted to describe, through three prototypical approaches, how distance education and teacher education can be connected or in the last approach even fused together. All programs benefit from additional educational research with regard to distance learning and advanced curriculum development.

As mentioned earlier this proposal aims to start a constructive and well-informed debate about the status of distance education in teacher education. The presented methodology is a first step in giving articulation to this goal. Future revision and re-examination are prerequisites for the development of the approaches. This puts the authors in a vulnerable position. The methodology, where different stakeholders are implemented, tries (at least to a certain extend) to overcome this. 


\section{References}

Albright, M., Simonson, M., Smaldino, S., \& Zvacek, S. (2009). Teaching and learning at a distance: Foundations of distance education ( $4^{\text {th }}$ ed.). Boston: Pearson.

Biggs, J. B. (2003). Teaching for quality learning at university ( $2^{\text {nd }}$ ed.). Buckingham: Open University Press/Society for Research into Higher Education.

Ehlers, J. (2006). Handbook on quality and standardisation in e-learning. Berlin: Springer.

Elen, J., Pynoo, B., Goeman, K., \& Van Braak, J. (2014). Betrokken, voorbeeldig, proactief: ICT-integratie in de lerarenopleiding. VELON Tijdschrift Voor Lerarenopleiders, 35(4), 1923.

Hannafin, M., Hannafin, K., Land, S., \& Oliver, K. (1997). Grounded practice and the design of constructivist learning environments. Educational Technology Research and Development, 45(3), 101-117.

Hirumi, A. (2002). The design and sequencing of e-Learning interactions: A grounded approach. International Journal on E-Learning, 1(1), 19.

Masschelein, J., \& Simons, M. (2012). Apologie van de school: Een publieke zaak (Educatieve ideeën: wereldse gebaren 5). Leuven: Acco.

Ossiannilsson, E., \& Landgren, L. (2012). Quality in e-learning - a conceptual framework based on experiences from three international benchmarking projects. Journal of Computer Assisted Learning, 28(1), 42-51. https://doi.org/10.1111/J.13652729.2011.00439.X

Wheeler, S. (2012). Distance Learning. In N. M. Seel (Ed.), Encyclopedia of the Sciences of Learning. Boston, MA: Springer.

\section{Acknowledgement}

All participant to the round table discussion are thanked for their constructive and rigorous feedback during the entire process of this article. 